\title{
Effect of Nano-Fertilization and Some Bio-Fertilizer on Growth, Yield and Fiber Quality of Egyptian Cotton.
}

\author{
Ahmed, H. S. A. ${ }^{(1)}$, Mona H. A. ${ }^{(2)}$ and Heba S.A. El-Desoukey. ${ }^{3}$ \\ (1) Cotton Research Institute, Agricultural Research Center, Giza, Egypt. \\ (2) Soil, Water and Environment Research Institute, Agricultural Research Center Giza, Egypt. \\ (3) Botany Department, Faculty of Agriculture, Benha University, Egypt \\ Corresponding author: heba.alabd@fagr.bu.edu.eg
}

\begin{abstract}
Two field experiments were conducted at Nubariya Research Station, Cotton Research Institute, Agricultural Research Center Giza, Egypt during the two summer growing seasons, 2017 and 2018. The aim of the present investigation was to study the effect of bio-fertilization Cyanobacteria extract, plant Growth promoting Rhizobacteria (PGPR) extract and Tea compost, nano-fertilization (NPK mixing) and their combination among $50 \%$ nano fertilization+ PGPR extract, $50 \%$ Nano fertilizers+ tea compost, $50 \%$ Nano +Cyanobacteria extract and $50 \%$ Nano+ PGPR extract+ tea compost+ Cyanobacteria extract and untreated one (control) on growth, seed yield , lint yield, and fiber properties of Egyptian cotton Giza 94 cultivar.

The most important results can be summarized as follows: the combined treatment which contains half dose of both the nano-fertilizer and the some biofertilizers gave the highest values for, i.e. plant height (cm), number of fruiting branches per plant, number of open bolls per plant, boll weight (gm), lint percentage, seed index, seed cotton yield (Kentar/fed.), lint cotton yield (Kantar/fed.), micronaire value, fiber maturity ratio (MR), upper half mean (UHM)mm, fiber uniformity index (UI), and fiber strength (g/tex), followed by the treatment of $100 \%$ nano then the recommended dose of mineral fertilizer NPK. On the other hand, the lowest values of all the above traits, were recorded from the half does of nano NPK fertilizer in 2017 and 2018 seasons, respectively . While, There were no significant differences between the means of the fiber elongation $\%$ due to the treatments applied during the study in 2017 season. It's worthily to mention that, the percentage of fiber elongation had no constant trend due to fertilizer transactions applied on the adopted genotype during` 2018 season. But, it seems to be that nanofertilizer is boosting the fiber elongation percent.
\end{abstract}

Key words:-Cotton plants, nano fertilizers, biofertilizers, PGPR, growth, yield, fiber properties.

\section{Introduction}

Nowadays, cotton faces problems causes retreating of its planting area year after year. One of the reasons make cotton lost its sustainability in Egypt is the production costs. Fertilization and harvesting exhibit the highest production cost. After building the high dam the Egyptian soil lost its fertility, farmers compensate this decrement by adding mineral fertilization. In fact, mineral fertilizer disadvantages are contaminate the soil, underground water which reflected badly on the living organism and human health as well as the cotton yield and the technological properties Arafa and Abd El-All (2013). Scientists try to solve these problems by using organic fertilizers then bio-organic fertilizers. Using organic fertilizer to improves the various physical properties of the soil which reflected positively on the crop quality and quantity. Arafa and Khalil (2013) reported that, mixed bacteria strains (PGPR) and organic matter increased the soil content of N, P, K elements along with the soil total fungi, bacteria actinomyces counts, as well as, boll weight (gm), lint percentage, seed index and seed cotton yield (Kentar/fed.), and fiber physical properties. Also, bio-fertilizer is one of natural and sustainable nutritional input. Mainly there are three types of bio-fertilizers which are used on mass scale. These are nitrogenous phosphoric, and potash biofertilizers. The use of Azotobacter enhances the yield of cotton depending on variety and strain efficiency, Shivalingaiah (2007) and Dhale et al., (2011).

In recent years, nanotechnology has extended its relevance in agriculture to improve fertilizer formulations for increased uptake in plant cells and by minimizing nutrient loss and increasing nutrient efficiency. Nanoparticles have high surface area, sorption capacity. The great surface area and small size of the nano-materials could lead to enhance the uptake efficiency of nutrients for plant cell (DeRosa et al. 2010).

Also, Nano-fertilizers may improve the uptake of root pores, or it could be facilitated by complication with molecular transporters or root, through the formation of new pores, or by exploitation of endocytosis or ion channels (Rico et al. 2011). Also, leaves containing nano and micro structured surfaces, called cuticle pores and stomata. A study on the penetration of two different sizes of water-suspended particles (43 $\mathrm{nm}$ or $1.1 \mu \mathrm{m}$ diameter) into leaves indicated that the nano-sized particles may enter the leaf through the stomatal pores (Eichert et al. 2008). A second study looking at pore diameters in a series of plant leaves found nano-sized pores in both stomata 
and a stomata leaf surfaces, although diameters varied widely. (Ramadan et al,. 2017) mentioned that, the combined treatment contains half dose of both the nano-fertilizer and the bio-organic fertilizer gave the highest results for plants plant height $(\mathrm{cm})$, number of fruiting branches per plant, number of open bolls per plant, boll weight $(\mathrm{gm})$, lint percentage, Seed index seeds, seed cotton yield (Kentar/fed.), lint cotton yield (Kentar/fed.), micronaire value, fiber maturity ratio (MR), upper half mean (UHM)mm, fiber uniformity index (UI), and fiber strength ( $\mathrm{g} /$ tex), followed by the treatment $100 \%$ nano then the recommended dose of mineral fertilizer NPK. On the other hand, the lowest values of all the above traits were recorded from the half does of NPK mineral fertilizers.

Nano -fertilizers are characterized by slow or controlled release mechanisms. They could precisely release their active ingredients in responding to environmental triggers and biological demands. These attributes of nanoparticles are due to their high surface area to volume ratio, high solubility, and specific targeting due to small size, high mobility, and low toxicity (Sasson et al. 2007).In general, Nano-scale fertilizer considered an innovative topic should be studied carefully to be aware by its influences on soil , environmental characters, crop growth, yield and quality,

\section{Materials and Methods}

Two field experiments were conducted at Nubariya Research Station, Cotton Research Institute, Agricultural. Research Center at Giza, Egypt during the two summer growing seasons, 2017 and 2018. The aim of the present study was to study the effect of the $100 \%$ nano NPK, plant Growth Promoting Rhizobacteria (PGPR) extract, tea compost, Cyanobacteria extract, combination among (50\% nano fertilization+ PGPR extract), (50\%Nano+tea compost), (50\% Nano +Cyanobacteria extract) and $(50 \%$ Nano+ PGPR extract+ tea compost+ Cyanobacteria extract) on growth, seed yield, lint yield , and fiber technological properties of Egyptian cotton Giza 94 cultivar.

The study included the following treatments:

(1) Control $100 \%$ mineral fertilizer (recommended dose $62 \mathrm{~kg} \mathrm{~N}, 30 \mathrm{~kg} \mathrm{~K}_{2} \mathrm{O} /$ and $22 \mathrm{~kg} \mathrm{P}_{2} \mathrm{O}_{5} /$ feddan, respectively.

$\begin{array}{ll}\text { (2) Cyanobacteria extract } & \text { (3) PGPR extract }\end{array}$ Tea compost

(5) $100 \%$ Nano NPK

(6) $50 \%$ Nano + PGPR extract

$\begin{array}{ll}\text { (7) } 50 \% \text { Nano + tea compost } & \text { (8) } 50 \% \text { Nano }\end{array}$ + Cyanobacteria extract

(9) $50 \%$ Nano + PGPR extract + tea compost + Cyanobacteria extract

The recommended fertilization dose for cotton are $60 \mathrm{~kg} \mathrm{~N}, 45 \mathrm{~kg} \mathrm{~K}$, and $22 \mathrm{~kg} \mathrm{P}_{2} \mathrm{O}_{5} /$ feddan their applied as a control. Nitrogen fertilizer added as ammonium nitrate $(33.5 \% \mathrm{~N})$ and calcium super phosphate $\left(15 \% \mathrm{P}_{2} \mathrm{O}_{5}\right)$ and potassium sulfate $\left(48 \% \mathrm{~K}_{2} \mathrm{O}\right)$. The nine previous treatments were arranged in complete block design with four replicates, the plot size was $4 \mathrm{~m} \mathrm{x}$ $3.6 \mathrm{~m}$ which contain 24 ridges.

\section{Preparing of Tea Compost:-}

The Compost was extract from compost made from rice straw and cattle dung which, had been composted in aerobic heap for three months. To prepare enriched complete compost quality, ten $\mathrm{kg}$ of mature compost immersed in appropriate volume of water for 7 days to produce the extract. The recommended value of extract was $20 \mathrm{~L} /$ feddan. Tea compost extract was mixed with PGPR into ratios 1:1 to produce bio- extracted tea compost. The analysis of compost tea is shown in Table (1).

Table 1. Nutrient contents of the extracted Tea compost.

\begin{tabular}{ll}
\hline \multicolumn{1}{c}{ Character } & Concentration \\
\hline Ammoniumic nitrogen mg/L & 20 \\
Nitrate nitrogen mg/L & 35 \\
Total nitrogen mg/L & 120 \\
Total Phosphorous mg/L & 60 \\
Total Potassium mg/L & 50 \\
COD mg/L & 980 \\
BOD mg/L & 435 \\
pH (1:10) & 8.04 \\
\hline
\end{tabular}

\section{Preparing PGPR extract:}

The bio-fertilizer Plant Growth Promoting Rhizobacteria (PGPR) was used in this study is a commercial multi strains of Pseudomonas putida, Bacillus megatherium, Azospirillum brasilense produced by culture collection in Agricultural Microbiology Department, Agricultural Research center Giza, Egypt. PGPR concentration was adjusted to $1 \times 10^{8}(\mathrm{cfu} / \mathrm{gr})$ for all treatments and sprayed in the recommended times of cotton fertilization with 20 L/feddan.

\section{Preparing Nano NPK:}

Nano fertilizer was prepared in lazier institute, Cairo University, according to Corradini et al., methodology (2010) with some modifications to exposed nano-fertilizers to high power of lazar ray. 


\section{Characterization of nano- fertilizer:}

Scanning of electronic microscope (SEM) images Fig.1 were taken with SEM Model Philips xL 30 attached with EDx Unit -5600 MD. At The Egyptian mineral resources authority, Central Laboratories Sector .The ministry of petroleum, Egypt Nanofertilizers concentration were $310 \mathrm{ppm} / \mathrm{L}$ as nitrogen ,60 ppm / L as phosphorus and $120 \mathrm{ppm} / \mathrm{L}$ as potassium .
Seeds of Egyptian cotton Giza 94 cultivar were sown on $10^{\text {th }}$ and $7^{\text {th }}$ of April in 2017 and 2018 respectively. All other agricultural practices i.e, irrigation, pest control and other managements were applied as the recommended. The experimental field soil was sampled initially before conducting the experiment to determine its physical and chemical analyses according to Jackson (1976).

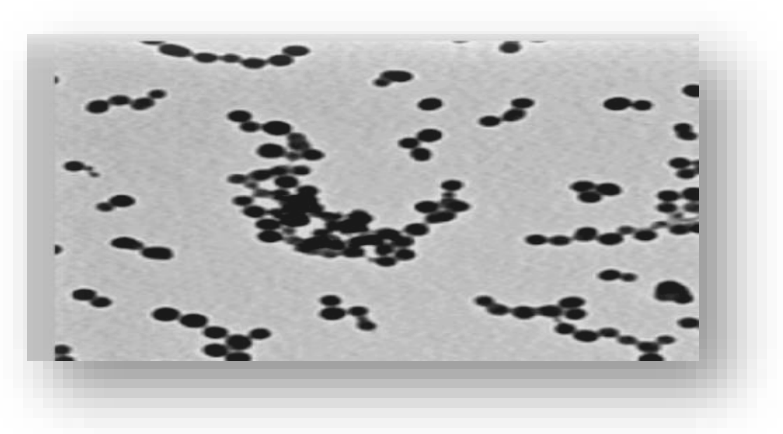

Figure (1). Scanning of Electronic Microscope images of Nano-particles (1: $100 \mathrm{~nm}$ ) of chitosan Nano- fertilizer.

Table 2. soil characteristics of soil analysis during 2017 and 2018 seasons.

\begin{tabular}{|c|c|c|c|}
\hline characters & elements & 2017 & 2018 \\
\hline \multirow{3}{*}{$\begin{array}{l}\text { Available macro } \\
\text { Nutrients (ppm) }\end{array}$} & $\mathbf{N}$ & 94.4 & 91.56 \\
\hline & $\mathbf{P}$ & 0.01 & 0.042 \\
\hline & $\mathbf{K}$ & 154.84 & 137.28 \\
\hline \multirow{4}{*}{ Solution Ions (ppm) } & $\mathbf{F e}$ & 0.95 & 1.10 \\
\hline & Mn & 0.7 & 0.88 \\
\hline & Zn & 0.13 & 0.04 \\
\hline & $\mathbf{C u}$ & 0.17 & 0.08 \\
\hline \multirow{3}{*}{ Chemical analysis } & PH & 8 & 7.79 \\
\hline & EC & 3.5 & 4.22 \\
\hline & SP \% & 70 & 70 \\
\hline \multirow{3}{*}{ Mechanical analysis } & Clay \% & 45.3 & 40.7 \\
\hline & Silt \% & 31.3 & 39.6 \\
\hline & Sand \% & 23.4 & 19.7 \\
\hline
\end{tabular}

\section{Sampling and collecting data}

Growth and yield characteristics:-

At harvest time ten plants were randomly collected from the inner ridges to determine the following at attributes: plant height $(\mathrm{cm})$, number of fruiting branches /plant, number of open bolls /plant, Boll weight $(\mathrm{g})$, lint percentage, seed index (100 seeds weight in g), seed cotton yield (Kentar/fed.) and Lint cotton yield (Kentar/fed.).

\section{Fiber properties:}

Fiber properties were estimated as micronaire value, fiber maturity ratio (MR), upper half mean (UHM) $\mathrm{mm}$, fiber uniformity index (UI), fiber strength ( $\mathrm{g} / \mathrm{tex})$, and fiber elongation percentage were determined using HVI instrument, all tested properties were done according to (ASTM: 1986). All properties were measured under standard conditions of $(65 \pm 5 \%)$ relative humidity and $\left(20 \pm 2 c^{\circ}\right)$ room temp. 
Table 3. Climatic Measurements for Egyptian cotton experiment during the two summer growing seasons 2017 and 2018.

\begin{tabular}{|c|c|c|c|c|c|c|c|c|c|c|c|c|}
\hline \multirow{3}{*}{ Month } & \multicolumn{6}{|c|}{2017} & \multicolumn{6}{|c|}{2018} \\
\hline & \multicolumn{2}{|c|}{ Temp. ${ }^{0} \mathrm{C}$} & \multicolumn{2}{|c|}{ RH\% } & \multicolumn{2}{|c|}{ Wind } & \multicolumn{2}{|c|}{ Temp. ${ }^{0} \mathrm{C}$} & \multicolumn{2}{|c|}{ RH\% } & \multicolumn{2}{|c|}{ Wind } \\
\hline & Max & Min & $7: 30$ & $13: 30$ & $\begin{array}{c}\text { velocity } \\
(\mathbf{k m} / 24 \mathbf{h r})\end{array}$ & $\begin{array}{l}\text { pan } \\
\text { evap } \\
(\mathbf{m m})\end{array}$ & Max & Min & $7: 30$ & $13: 3$ & $\begin{array}{c}\text { velocity } \\
(\mathbf{k m} / 24 \mathrm{hr})\end{array}$ & $\begin{array}{c}\text { pan } \\
\text { evap } \\
(\mathbf{m m})\end{array}$ \\
\hline April & 27.66 & 15.64 & 82 & 50 & 93 & 507.939 & 22.25 & 13.81 & 77 & 48 & 96 & 661.796 \\
\hline May & 29.27 & 19 & 77 & 52 & 101 & 588.23 & 30.29 & 18.85 & 76.0 & 46 & 114 & 680.6 \\
\hline June & 32.48 & 21.19 & 73 & 64 & 86 & 419.33 & 52.24 & 20.68 & 79 & 51 & 106 & 679.2 \\
\hline Jul & 22.15 & 22.41 & 55 & 55 & 97 & 757.53 & 32.99 & 22.41 & 86 & 37 & 97 & 699 \\
\hline Aug. & 34.03 & 21.84 & 92 & 38 & 99 & 790.0 & 35.16 & 24.33 & 84 & 53 & 91 & 809.1 \\
\hline Sep. & 32.55 & 20.77 & 88 & 51 & 93 & 443.93 & 33.53 & 23.14 & 82 & 47 & 94 & 653.9 \\
\hline Oct. & 28.92 & 18.71 & 79 & 53 & 83 & 450.07 & 34.34 & 23.73 & 83 & 50 & 92 & 731.5 \\
\hline
\end{tabular}

Statistical analysis: Obtained data was statistically analyzed L.S.D at $5 \%$ according to Snedecor and Cochran (1980)

\section{Results and Discussion}

\section{I- Growth characteristics:}

\section{I.1. Final plant height $(\mathrm{cm})$ :}

Data in Table (4) indicated that organic, mineral and nano-fertilization for Giza 94 had significant effect on final plant height. These effects were appeared during the two growing season; 2017 and 2018. The obtained results indicated that the complex treatment contains half dose of both the nano-fertilizer and the 50\% Nano NPK + bio-organic fertilizer (tea compost) gave the highest plants in 2017 and 2018 seasons followed by ( $50 \%$ Nano+ PGPR extract+ tea compost+ Cyanobacteria extract) treatment then the recommended dose of control. On the contrary, the transaction contains Cyanobacteria extract gave the shortest plants in 2017 and 2018 seasons. These results may explained that, bio fertilizer able to augment the plants by interfering the concentration of known phytohormone those bacteria one of the most important way on affect in the growth and development by producing Indole- 3 acetic acid (IAA) that hormone is led to plant shoot and root growth, development and subsequently increase uptake of nutrients by plant. Also, nano-fertilizer increased uptake in plant cells by minimizing nutrient loss and increase the nutrient use efficiency. These results are in agreement with the results obtained by, Etesami $\boldsymbol{e t}$ al., (2009) and Ghormade et al., (2011), who found that, nano-particles fertilizers can make modification of plant gene expression and associated biological pathways which ultimately affect plant growth, height and development.

I.2. No. of fruiting branches (sympodia) per main stem:

Data illustrated in Table (4) revealed that no. of fruiting branches were affected significantly by fertilizer transactions. These results were fairly true in the two growing seasons 2017 and 2018. The treatment of $(50 \%$ Nano+PGPR extract + tea compost +Cyanobacteria extract) gave the highest values of sympodia per plant (15.73 and 16.74), followed by $50 \%$ nano-fertilizer+ tea compost treatment (15.71 and 16.70) as compared to the recommended dose of NPK mineral fertilizer in 2017 and 2018 seasons, respectively. On the other hand, the lowest values of sympodia on the main stem (13.86 and 14.93), were recorded from the $50 \%$ Nano +Cyanobacteria extract fertilizer in 2017 and 2018 seasons, respectively. This trend is expected since plant takes sufficient nutrients produced the first sympodium at a lower location than that in deprived ones. These results are in conformity with those obtained by Moore 2006; Navarro et al., (2008), and Kottegoda et al., (2011a) who, found that, functionalized nano-particles facilitate the enlargement of pore size or induction of new cell wall pore to enhance the uptake of nutrient which had significantly increase the vegetative growth and number of sympodia on the main stem.

\section{I.3. Boll weight /plant:}

Data belonging to the boll weight of the investigated Giza 94 cotton cultivar under adopted treatments in the two experimental seasons were statistically significant in both seasons, and represented in Table (4). It obvious that, the complex treatment between $(50 \%$ Nano+ PGPR extract+ tea compost+ Cyanobacteria extract) for both of them exhibited the harvest values of boll weight (2.75 and 2.71 gram) in both seasons, respectively followed by compost Tea then $100 \%$ NPK as a mineral fertilizer. In contrast, the treatment of Cyanobacteria extract fertilizer recorded the lowest values (2.31 and 2.25 gram) in 2017 and 2018 season, respectively. This may be due to that nano-materials are more reactive, greater access than larger particles this lead to the great amount of the dry matter used to produce bolls. Which, resulted from the great vegetative growth than the others treatments under study. 
Table 4. Effect of nano-fertilization and some bio-fertilizers on Plant height( $\mathrm{cm})$, no. of fruiting branches and Boll weight (gm) of Egyptian cotton Giza-94 during 2017 and 2018 seasons.

\begin{tabular}{|c|c|c|c|c|c|c|}
\hline \multirow[t]{2}{*}{ Characters } & \multicolumn{2}{|c|}{ Plant high(cm) } & \multicolumn{2}{|c|}{$\begin{array}{c}\text { Num. of fruiting } \\
\text { branches/plant }\end{array}$} & \multicolumn{2}{|c|}{ Boll weight (g) } \\
\hline & 2017 & 2018 & 2017 & 2018 & 2017 & 2018 \\
\hline Control 100\%NPK & 161.90 & 165.00 & 15.31 & 16.33 & 2.60 & 2.46 \\
\hline Cyanobacteria extract & 139.10 & 143.00 & 12.93 & 13.96 & 2.31 & 2.25 \\
\hline PGPR extract & 143.18 & 147.20 & 14.15 & 14.60 & 2.41 & 2.37 \\
\hline Tea compost & 155.23 & 158.32 & 15.22 & 16.27 & 2.70 & 2.47 \\
\hline $100 \%$ Nano NPK & 147.01 & 151.10 & 14.35 & 16.13 & 2.45 & 2.44 \\
\hline $50 \%$ Nano + PGPR extract & 151.20 & 154.60 & 14.40 & 16.30 & 2.50 & 2.41 \\
\hline $50 \%$ Nano + tea compost & 163.21 & 166.24 & 15.71 & 16.70 & 2.76 & 2.66 \\
\hline $50 \%$ Nano +Cyanobacteria extract & 144.23 & 147,60 & 13.86 & 14.93 & 2.40 & 2.31 \\
\hline $\begin{array}{l}50 \% \text { Nano + PGPR extract }+ \text { tea } \\
\text { compost + Cyanobacteria extract }\end{array}$ & 160.20 & 165.24 & 15.73 & 16.74 & 2.75 & 2.71 \\
\hline L.S.D 5\% & 1.01 & 1.03 & 3.03 & 2.89 & 0.042 & 0.14 \\
\hline
\end{tabular}

\section{I.4. Number of opened bolls:}

Data presented in Table (5) indicated that number of opened bolls/plants influenced statistically by fertilizer treatments in 2017 and 2018 seasons. The PGPR extract fertilizer application surpassed the other treatments (21.63 and 21.58) in the two studied seasons. Also, the treatment of $(50 \%$ Nano+ PGPR extract+ tea compost+ Cyanobacteria extract) gave positive impact in opened bolls. On contrast, the treatment containing the $50 \%$ Nano +Cyanobacteria extract fertilization gave the lowest values (14.50 and 13.93) in 2017 and 2018 seasons respectively. This may be due to that both bio fertilization and nanofertilizers can boost the nutrient use efficiency through mechanisms, called slow release. They could exactly release their ingredient in responding to biological demands, adding to that nano-fertilizers can improve crop productivity by enhancing germination, seedling growth, photosynthetic activity, nitrogen metabolism, both of carbohydrate synthesis and protein creation. These results are in harmony with those reported by Arafa and Abd El-All (2013), Arafa et al., (2013)

\section{I.5. Seed cotton yield (kg/f.)}

It is worthy to mention that, data belonging to seed cotton yield (kg/f.) were significant increase in both seasons, it is obvious from Table (5) that all the seed cotton yield $(\mathrm{kg} / \mathrm{f})$ gaving express high crop yield regardless the treatment.This true, since the current Egyptian cultivar usually associated with high crop yield except, the treatments of bio fertilizer, because the ratio of fertilizer not adequate for normal dry matter deposition. Thus, the treatment including (50\%
Nano+ PGPR extract+ tea compost+ Cyanobacteria extract) gave the maximum seed cotton yield $\mathrm{kg} / \mathrm{f}$. (13.56 and 13.36) in 2017 and 2018 growing seasons, respectively. followed by PGPR extract treatment then the recommended dose of $100 \%$ Nano NPK. on the contrary, the transaction contains half recommended dose of Cyanobacteria extract gave the lowest seed cotton yield $\mathrm{kg} / \mathrm{f}$. (9.37 and 9.11) in 2017 and 2018 seasons, respectively.

\section{I.6. Lint cotton yield (kg/f.)}

Lint cotton yield $(\mathrm{k} / \mathrm{f})$ as affected by mineral, bio- fertilizer, and nano-fertilizer and their combinations in 2017 and 2018 growing seasons are given in Table (5) Data indicated that, the effects were significant in both studied seasons. The transaction containing both of the bio- fertilizer and the nanofertilizer with ratio $0.5: 1$ exhibited the highest lint cotton yield (kg/f.) (4.65 and $4.59 \mathrm{k} / \mathrm{f})$ in both seasons, respectively, as comparing to the recommended dose of $50 \%$ nano +Cyanobacteria extract fertilizer; while, the lowest values (3.19 and $3.16 \mathrm{~K} / \mathrm{F}$ ) in 2017 and 2018 seasons, respectively were obtained from the half the recommended dose of mineral fertilizers. indicating the benefits and positive effect of Nano and bio-fertilizer is such able when the organic matter is found this may be due to that PGPR works in its best way when the $\mathrm{pH}$ of soil is acedic due to the decrease in soil $\mathrm{pH}$ due to tea compost activate the soil bacteria and the ability of root uptake which reflected in plant metabolism Arafa et al., (2013). As well as, the benefits of nano-fertilizer as inferred before. 
Table 5. Effect of nano-fertilization and some bio-fertilizers on Num.er of opened bolls, seed cotton yield and lint cotton yield of Egyptian cotton Giza-94 during 2017 and 2018 seasons.

\begin{tabular}{|c|c|c|c|c|c|c|}
\hline \multirow[t]{2}{*}{ Characters } & \multicolumn{2}{|c|}{$\begin{array}{c}\text { Num. of opened } \\
\text { bolls/plant }\end{array}$} & \multicolumn{2}{|c|}{$\begin{array}{l}\text { Seed cotton } \\
\text { yield }(\mathrm{kg} / \mathrm{f} .)\end{array}$} & \multicolumn{2}{|c|}{$\begin{array}{l}\text { lint cotton } \\
\text { yield }(\mathrm{kg} / \mathrm{f} .)\end{array}$} \\
\hline & 2017 & 2018 & 2017 & 2018 & 2017 & 2018 \\
\hline Control 100\%NPK & 18.12 & 18.05 & 11.70 & 11.26 & 4.09 & 4.02 \\
\hline Cyanobacteria extract & 15.50 & 15.46 & 9.37 & 9.11 & 4.07 & 4.11 \\
\hline PGPR extract & 21.63 & 21.58 & 13.47 & 13.20 & 4.39 & 4.35 \\
\hline Tea compost & 18.80 & 18.78 & 12.17 & 13.58 & 4.35 & 4.34 \\
\hline $100 \%$ Nano NPK & 19.00 & 18.26 & 12.49 & 12.23 & 4.86 & 4.64 \\
\hline $50 \%$ Nano + PGPR extract & 19.00 & 15.30 & 12.50 & 12.04 & 4.88 & 4.80 \\
\hline $50 \%$ Nano + tea compost & 14.67 & 14.25 & 12.06 & 11.86 & 4.53 & 4.18 \\
\hline $50 \%$ Nano +Cyanobacteria extract & 14.50 & 13.93 & 9.76 & 9.21 & 3.19 & 3.16 \\
\hline $\begin{array}{l}50 \% \text { Nano }+ \text { PGPR extract }+ \text { tea compost }+ \\
\text { Cyanobacteria extract }\end{array}$ & 21.59 & 21.26 & 13.56 & 13.86 & 4.65 & 4.59 \\
\hline L.S.D 5\% & 0.34 & 1.56 & 0.50 & 0.24 & 0.37 & 0.34 \\
\hline
\end{tabular}

\subsection{Seed index:}

The influence of treatments applied during the study on this character was given in Table (6) Seed index values were affected significantly by the application of the studied fertilizer treatments. These results were fairly true in two growing seasons; 2017 and 2018. It is obvious that nano-fertilizer is boosting the seed index. The combination between the PGPR extract gave the largest values of seed index (12.76 and 12.75) in both seasons, respectively, followed by (50\% Nano+ PGPR extract+ tea compost+ Cyanobacteria extract) treatment. On the other hand, the lowest values (10.50 and 10.36) were obtained from Cyanobacteria extract of the recommended dose of the mineral fertilizer in 2017 and 2018 seasons, respectively. These results indicated that both nano fertilizer and bio- fertilizer led to more accumulation of dry matter in cotton seeds, which reflected positively on seed index.

\subsection{Lint percentage:}

Data in Table (6) indicated that bio fertilization and nano-fertilization for Giza 94 genotype had significant effect on lint percentage. These effects were appeared during the two growing season; 2017 and 2018 seasons. The results obtained that, indicated that the complex treatment contains half dose of both the nano-fertilizer and the bio- fertilizer gave the greatest value of lint percentage (41.27 and 41.45) in 2017 and 2018 seasons, respectively followed by (50\% Nano+ PGPR extract+ tea compost+ Cyanobacteria extract) treatment (40.53 and 39.96) then the recommended dose of PGPR extract treatment. On the contrary, the transaction contains Cyanobacteria extract gave the lowest readings (35.06 and 34.96) in 2017 and 2018 seasons, respectively. These results may explained that, bio- fertilizer able to augment the plants by interfering the concentration of known phytohormone that those bacteria one of the most important way affect the growth and development by increase uptake of nutrients by plant. Also, nano-fertilizer increased uptake in plant cells by minimizing nutrient loss and increase the nutrient use efficiency. These results are in agreement with the results obtained by, Etesami et al., (2009) and Ghormade et al., (2011), who found that, nanoparticles fertilizers can result in modification of plant gene expression and associated biological pathways which ultimately affect plant yield

Table 6. Effect of nano-fertilization and some bio-fertilizers on seed index lint percentage, of Egyptian cotton Giza-94 during 2017 and 2018 seasons.

\begin{tabular}{|c|c|c|c|c|}
\hline \multirow[t]{2}{*}{ Characters } & \multicolumn{2}{|c|}{ seed index } & \multicolumn{2}{|c|}{ lint percentage } \\
\hline & 2017 & 2018 & 2017 & 2018 \\
\hline Control $100 \%$ NPK & 11.52 & 11.09 & 39.78 & 38.45 \\
\hline Cyanobacteria extract & 10.50 & 10.36 & 35.06 & 34.96 \\
\hline PGPR extract & 12.76 & 12.75 & 40.53 & 39.96 \\
\hline Tea compost & 12.55 & 12.44 & 39.82 & 39.16 \\
\hline $100 \%$ Nano NPK & 11.42 & 11.32 & 39.80 & 38.58 \\
\hline $50 \%$ Nano + PGPR extract & 12.51 & 11.83 & 38.70 & 38.20 \\
\hline $50 \%$ Nano + tea compost & 11.10 & 10.96 & 38.25 & 36.47 \\
\hline $50 \%$ Nano +Cyanobacteria extract & 10.83 & 10.70 & 36.20 & 34.95 \\
\hline $\begin{array}{l}50 \% \text { Nano + PGPR extract }+ \text { tea compost }+ \\
\text { Cyanobacteria extract }\end{array}$ & 12.59 & 12.45 & 41.27 & 41.45 \\
\hline L.S.D 5\% & 0.22 & 0.34 & 1.30 & 1.12 \\
\hline
\end{tabular}


II. Fiber physical properties:

II.1 Fiber Upper Half Mean (mm):

Data in Table (7) represents the significant effect of bio-fertilization (Cyanobacteria extract, PGPR extract, Tea compost) nano-fertilization (NPK) and their combination on Upper Half Mean (mm) UHM reading of Giza 94 cultivar in both the studied seasons

It is evident that UHM reading ranged from $33.93 \mathrm{~mm}$ to $32.90 \mathrm{~mm}$ in 2017 season and from 33.92 $\mathrm{mm}$ to $32.82 \mathrm{~mm}$ in 2018 season indicating the positive effect of the combination between nano and bio -fertilizers in improving fiber length by $0.8 \mathrm{~mm}$ and $1.1 \mathrm{~mm}$ in 2017 and 2018 growing seasons, respectively than the recommended doses of PGPR extract. These results are acceptable since, fiber growth is known to occur in two fairly distinct stages, the first growth stage corresponds to the fiber elongation and the second growth stage corresponds to the secondary wall formation. The period of elongation seems to be determined by genotype to give its standard length and its effect by the growing conditions is limited. These results are in line with those of Khalil and Arafa (2013) and Arafa and Abd El-All (2013).

\section{II.2 Fiber uniformity index (UI):}

The results in Table (7) represent the effect of the considered cultivar under adopted treatments in the two seasons on fiber uniformity index. It could be recognized that the effects of the fertilizer and their combinations treatments were significant in both seasons. The combination between the nano-fertilizer and bio- fertilizer in ratio of $0.5: 1$ gave the largest values of fiber uniformity index (85.37 and 85.31$)$ in
2017 and 2018seasons, respectively. On the other hand, the lowest values were obtained from $50 \%$ of the recommended dose of the mineral fertilizer in 2017 and 2018 seasons, respectively. These results indicated that both nano and bio-organic fertilizer led to more accumulation of dry matter in cotton fibers, and increase the cellulose deposition in the secondary walls which forms the body of the fiber. This led to more strength and less rupture in fiber which reflected positively on uniformity index.

\section{II.3 Fiber strength (g/tex):-}

Fiber strength as affected by mineral, bio-organic, and nano-fertilizer and their combinations in 2017 and 2018 growing seasons are given in Table (7) data indicated that, the effects were significant in both studied seasons. The transaction containing both of the bio-organic and the nano-fertilizer with ratio of 1:0.5 exhibited the strongest fibers (43.92 and 43.93 $\mathrm{g} /$ tex) in both seasons, respectively, as comparing to the recommended dose of (50\% Nano+ PGPR extract +tea compost+ Cyanobacteria extract). while, the weakest fiber strength values (42.25 and $42.32 \mathrm{~g} / \mathrm{tex}$ ) in 2017 and 2018 seasons, respectively were obtained from the half of the recommended dose of $(50 \%$ Nano + Cyanobacteria extract). indicating the benefits and positive effect of bio-fertilizer is such able when the organic matter is found this may be due to that PGPR works in its best way when the $\mathrm{pH}$ of soil is acedic due to the decrease in soil $\mathrm{pH}$ due to tea compost activate the soil bacteria and the ability of root uptake which reflected in plant metabolism Arafa et al., (2013). As well as, the benefits of nano-fertilizer as inferred before.

Table 7. Upper half mean (mm) (U.H.M), Uniformity index (U.I), and fiber strength (g/tex) as affected by nanofertilization and some bio-fertilizer for Giza 94 cultivar during 2017 and 2018 seasons.

\begin{tabular}{|c|c|c|c|c|c|c|}
\hline \multirow{2}{*}{$\begin{array}{ll}\text { Characters } & \\
\text { Treatments }\end{array}$} & \multicolumn{2}{|c|}{ U.H.M(mm) } & \multicolumn{2}{|c|}{ U.I } & \multicolumn{2}{|c|}{ fiber strength(g/tex) } \\
\hline & 2017 & 2018 & 2017 & 2018 & 2017 & 2018 \\
\hline Control 100\%NPK & 32.90 & 32.82 & 83.33 & 88.32 & 42.35 & 42.57 \\
\hline Cyanobacteria extract & 33.66 & 33.52 & 84.72 & 84.69 & 42.99 & 42.32 \\
\hline PGPR extract & 33.93 & 33.83 & 84.95 & 85.90 & 42.90 & 42.81 \\
\hline Tea compost & 33.53 & 33.40 & 85.37 & 85.31 & 42.31 & 42.20 \\
\hline $100 \%$ Nano NPK & 33.46 & 33.35 & 85.14 & 85.45 & 42.37 & 42.32 \\
\hline $50 \%$ Nano + PGPR extract & 33.52 & 33.46 & 85.35 & 85.35 & 42.79 & 40.17 \\
\hline $50 \%$ Nano + tea compost & 33.37 & 33.30 & 85.72 & 85.70 & 43.65 & 43.64 \\
\hline $\begin{array}{l}50 \% \text { Nano +Cyanobacteria } \\
\text { extract }\end{array}$ & 33.26 & 33.00 & 84.64 & 84.62 & 42.25 & 42.32 \\
\hline $\begin{array}{l}50 \% \text { Nano + PGPR extract }+ \\
\text { tea compost + Cyanobacteria } \\
\text { extract }\end{array}$ & 33.89 & 33.92 & 85.75 & 85.73 & 43.92 & 43.93 \\
\hline L.S.D 5\% & 0.56 & 0.25 & 0.42 & 0.24 & 1.56 & 1.01 \\
\hline
\end{tabular}

\section{II.4 The percentage of fiber elongation:}

The influence of treatments applied during the study on this character was given in Table (8)There were no significant differences between the means of the fiber elongation $\%$ due to the treatments applied during the study in 2017 season ; While, it was significant in 2018 season.
It's worthy to mention that, the percentage of fiber elongation had no constant trend due to fertilizer transactions applied on the adopted cultivar during` 2018 season. But, it seems to be that nano-fertilizer is boosting the elongation percent. Ramadan et al,. (2017) While, There were no significant differences 
between the means of the fiber elongation $\%$ due to the treatments applied during the study.

\section{5 Micronaire value:}

Data presented in Table (8) revealed that micronaire values were affected significantly by the application of the studied fertilizer treatments. These results were fairly true in two growing seasons; 2017 and 2018.

It could be arranged in descending order with regard to micronaire values as follows: (50\% Nano+ PGPR extract + tea compost+ Cyanobacteria extract) (4.93 and 4.90), PGPR extract (4.46 and 4.43), 100\% nano NPK (4.42 and 4.41) then the rest treatments in 2017 and 2018 growing seasons, respectively.

The inferred result indicated that, micronaire values tended to increase by applying nano-fertilizer this could be attributed to fact that micronaire values incorporates both intrinsic fineness and maturity, when samples belongs to the same genotype the different micronaire values express difference in maturity because fineness is limited by the genotype

So, the increment in micronaire value may be ascribed to the increasing in fiber maturity as a direct impact of both of the bio- fertilizer and nano- fertilizer in plant metabolism and the other vital activities. Similar trend was observed by Moore 2006; Navarro et al., (2008), Arafa and Khalil. (2013), Kottegoda et al., (2011), Arafa et al., (2013) and Ramadan et al, (2017)

\section{6 Fiber maturity ratio:}

It is worthy to mention that, data belonging to fiber maturity ratio were significant in both seasons, it's obvious from Table (8) that all the maturity reading express high maturity ratio regardless the treatment .This true, since the Egyptian genotypes usually associated with high maturity ratio except, the treatments of bio- fertilizer or nano-fertilizer, because the ratio of fertilizer not adequate for normal cellulose deposition as it well known that; fiber growth is known to occur in two fairly distinct stages, the first growth stage corresponds to the fiber elongation and the second growth stage corresponds to the secondary wall formation.

The period of elongation seems to be determined by genotype; however second growth stage is influenced by the growing conditions such as, nutrients uptake. This explained the increment in fiber maturity in the treatment including $(50 \%$ Nano+ PGPR extract+ tea compost+ Cyanobacteria extract) (1.0 and 0.98) in 2017 and 2018 growing seasons, resp. Similar trend was observed by Arafa et al., (2013) and Ramadan et al, (2017).

Table 8. Elongation \%, maturity ratio and micronire reading as affected by nano-fertilization and some biofertilizers under Giza 94 cotton cultivar growing during 2017 and 2018 seasons.

\begin{tabular}{|c|c|c|c|c|c|c|}
\hline \multirow[t]{2}{*}{ Characters } & \multicolumn{2}{|c|}{ elongation \% } & \multicolumn{2}{|c|}{$\begin{array}{l}\text { micronire } \\
\text { reading }\end{array}$} & \multicolumn{2}{|c|}{ maturity ratio } \\
\hline & 2017 & 2018 & 2017 & 2018 & 2017 & 2018 \\
\hline Control $100 \%$ NPK & 9.19 & 9.13 & 4.30 & 4.28 & 0.96 & 0.95 \\
\hline Cyanobacteria extract & 9.11 & 9.10 & 4.37 & 4.38 & 0.87 & 0.88 \\
\hline PGPR extract & 9.21 & 9.19 & 4.46 & 4.43 & 0.98 & 0.99 \\
\hline Tea compost & 9.21 & 9.14 & 4.36 & 4.32 & 0.95 & 0.98 \\
\hline $100 \%$ Nano NPK & 9.15 & 9.13 & 4.42 & 4.41 & 0.96 & 0.94 \\
\hline $50 \%$ Nano + PGPR extract & 9.19 & 9.13 & 4.30 & 4.31 & 0.96 & 0.94 \\
\hline $50 \%$ Nano + tea compost & 9.14 & 9.12 & 4.33 & 4.30 & 0.93 & 0.93 \\
\hline $50 \%$ Nano +Cyanobacteria extract & 9.21 & 9.11 & 4.40 & 3.41 & 0.94 & 0.93 \\
\hline $\begin{array}{l}50 \% \text { Nano + PGPR extract }+ \text { tea compost } \\
+ \text { Cyanobacteria extract }\end{array}$ & 9.24 & 9.22 & 4.93 & 4.90 & 1.0 & 0.98 \\
\hline L.S.D $5 \%$ & 0.02 & N.S. & 0.07 & 0.71 & 0.02 & 0.01 \\
\hline
\end{tabular}

\section{Conclusion}

In general, the present study strongly admit the use of each bio fertilization and nano fertilizers in Egyptian cotton cultivation as in case of Giza 94 cultivar to improve its growth, productivity and quality as well.

\section{References}

Arafa, A.S. and Khalil, A. (2013) Evaluation of the technological properties of bio-organic colored cotton J. of agronomy. 12(2).78-85.

Arafa, A.S. and Abd El-All., A. M. (2013) Evaluation of the Technological properties of the bio-organic colored cotton. J. of agronomy. 12(2).78-85.
Arafa, A.S.; Khalil, H, M. and Gebaly, S G. (2013). Impact of eco- friendly fertilizers and rice straw on cotton yield and fiber physical properties .International Sci. and Investigation J. 8(2).

ASTM American stander for testing materials 1986.USA.

Corradini, M.; de Moura, R. and Mattoso, L. H.C. (2010) Polymer Letter Vo. 1.4, No. 8.509-515

DeRosa, M.C; Monreal, C.; Schnitzer, M.; Walsh, R., and Sultan, Y. (2010) Nanotechnology in fertilizers. Nat Nanotechnology 5:91

Dhale, D. A.; Chatte, S. N. and Jadhav, V. T. (2011) Response of bioinoculents on growth, yield and fiber quality of cotton under irrigation. 
Agricultural and biology journal of north America. Science Huß,

Eichert, T; Kurtz, A; Steiner, U and Goldbach, H.E. (2008) Size exclusion limits and lateral heterogeneity of the stomatal foliar uptake pathway for aqueous solutes and water-suspended nanoparticles. Physiol Plant 134:151-160

Etesami, H.; Hossein A., A. and Abolfazl, A.A. (2009). Evaluation of Plant Growth Hormones Production (IAA) Ability by Iranian Soils Rhizobial Strains and Effects of Superior Strains Application on Wheat Growth Indexes., World Applied Sciences Journal 6 (11): 1576-1584.

Ghormade, V,;Deshpande, M.V and Paknikar, K.M. (2011) Perspectives for nano-biotechnology enabled protection and nutrition of plants. Biotechnol Adv 29:792-803

Khalil, H M. and Arafa A.S. (2013) Influence rice straw and bio organic fertilization on cotton fiber quality under saline soils. J. of agronomy. 12(2).86-92.

Jackson, M.L. (1976). "Soil chemical analysis". Prentice- Hall, Inc. Engle Wood Cliffs, N.J., 498 PP.

Kottegoda, N.; Munaweera, I., Madusanka, A.N. and Karunaratne, V. (2011a) Compositions for sustained.release of agricultural macronutrients and process thereof. WO 2011151724

Moore, M. (2006). Do nanoparticles present ecotoxicological risks for the health of the aquaticenvironment? Environ Int 32:967-976

Navarro, E.; Baun, A.; Behra, R.; Hartmann, N.B.; Filser, J.; Miao, A.J.; Quigg, A.; Santschi, P.H., and Sigg, L. (2008). Environmental behavior and ecotoxicity of engineered nanoparticles to algae, plants,and fungi. Ecotoxicology 17:372-386

Ramadan, T.; Abdrabou, A. S.; Arafa, G.; Ahmed, Abd Elsamad, A. and Ahmed, K. M. (2017) The combined effect of different nitrogenous Impact of N.P.K nano-fertilization on yield and some lint properties of Egyptian cotton. International Conference of Textile Research Division Textile Processing: State of the Art \& Future Development from Laboratory to Factory Cairo, Egypt.

Rico, C.M.; Majumdar, S.; Duarte-Gardea, M.;Peralta-Videa, J.R. and Gardea-Torresdey, J.L. (2011) Interaction of nanoparticles with edible plants and their possible implications in the food chain. J Agric Food Chem 59:3485-3498

Sasson, Y.; Levy-Ruso, G.; Toledano, O. and Ishaaya, I. (2007) Nanosuspensions: emerging novel agrochemical formulations. In: Ishaaya I, Horowitz AR, Nauen R (eds) Insecticides design using advanced technologies. Springer, Berlin, pp 1-39

Sendecore, G.W. and Cochran, W.G. (1980). Statistical Methods .7th ed . Iowa State Univ., Press, Ames, IA.

Shivalingaiah, M. (2007) Effect of nutrient management and plant protection practices in organic cotton production (Gossypium spp.) M.Sc. Thesis, University of Agricultural Sciences, Dharwad

Simon, T.S. and Ross, A. F. (1971). Changes in phenol metabolism associated with inclosed systemic resistance to tobacco mosic virus Sum sun NN tobacco phytopathology. 61: 126-1265. 
تأثير التسميد بالنانو ويعض المركبات الحيويه علي النمو والمحصول وجودة التيله فى القطن المصري.

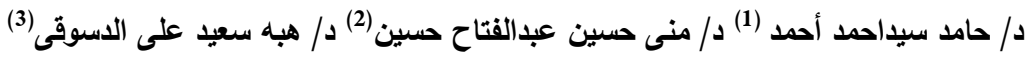

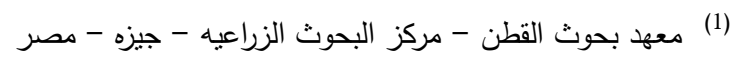

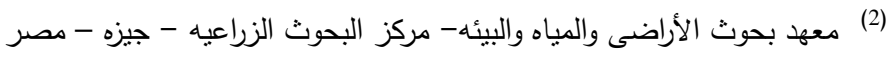

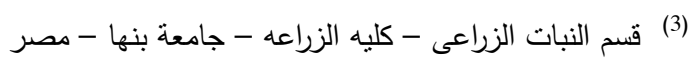

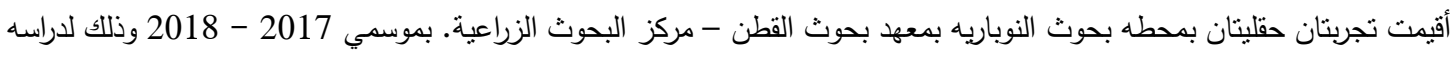

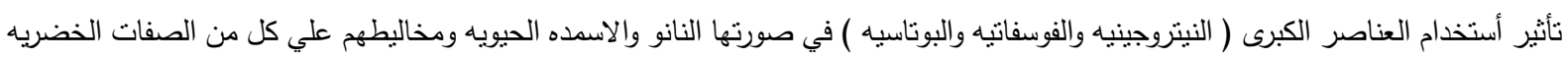

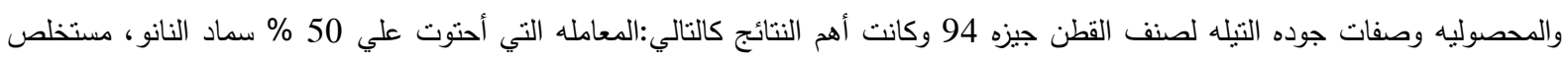

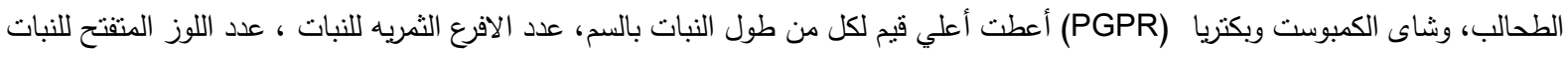

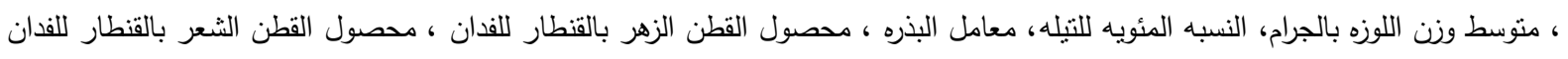

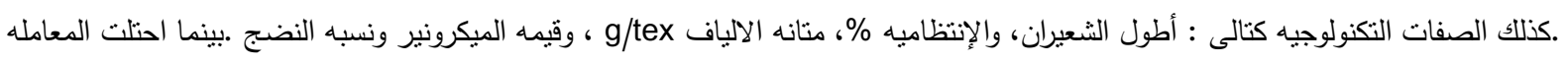

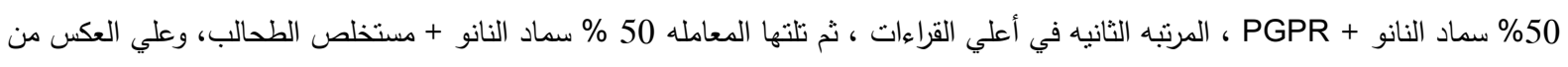

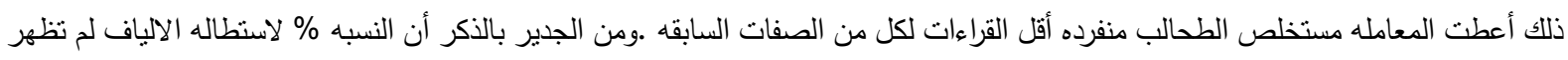

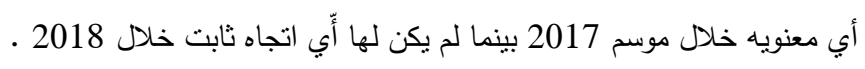

